\title{
$\mathrm{Y}$ 系超電導体を用いた真空用 $X-Y 2$ 自由度 マイクロアクチュエータ
}

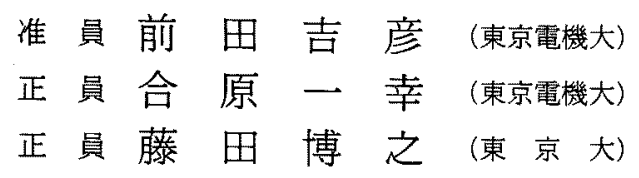

\section{$X-Y$ Two-Degree-of-Freedom Typed Micro Actuator Using Yttrium High Temperature Superconductors for Vacuum Condition}

Yoshihiko Maeda, Associate, Kazuyuki Aihara, Member (Tokyo Denki University), Hiroyuki

Fujita, Member (University of Tokyo)

In this paper, the design, the fabrication and the operation of two dimensional micro actuators using Yttrium High Temperature Super-Conductors (HTSC) in vacuum condition are reported. This microactuator consists of two parts; (a) a slider made by a permanent magnet, (b) a stator with patterned electrodes on bulk HTSC. The slider is levitated by repulsive force between the magnet and HTSC, when HTSC is cooled by liquid nitrogen. We can control the position of the slider by switching current in electrodes using Lorentz forces between the current and the magnet. The maximum speed of the sliders is $37 \mathrm{~mm} / \mathrm{s}$ at the driving current of $400 \mathrm{~mA}$. Two dimensional position control of the slider is achieved in this study with strokes of a few millimeters for each direction.

キーワード : 高温超電導, $\mathrm{Y}$ 系超電導体, 磁気浮上, 超電導アクチュエータ, マイクロアクチュエー 夕, ピン止め力

\section{1. まえがき}

近年, 集積回路の製作に用いる半導体プロセス技術

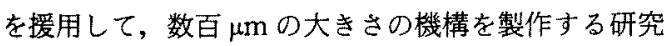
が行われている(1) ー(3)。

このような大きさになると, 従来の機械のように一 つ一つの部品を組立てて作り上げるという作業は非常 に困難になる。そこで，半導体プロセス技術を用い て, 複雑なシステムの一括製作を行うことが有効にな る。更に，このプロセスを用いて製作される回路やセ ンサを集積化することも期待される。このような超小 型システムの研究は“マイクロメカトロニクス”と呼ば れる(4)。このサイズの機構では，マクロな世界におけ る負荷として支配的であった，慣性力などの体積に依 存する負荷に代わり，面の接触による摩擦力の上うな
表面積に依存する力が相対的に大きな負荷となる。そ こで，ミクロの世界における駆動と運動制御では可動 部分と固定部分との表面の間に慟く摩擦の問題(5)(6) が 重要になる。すなわち、アクチュエータ自体が小さい ためその駆動力は非常に小さく，摩擦負荷により動か なくなったり，極めて断続的な動きをしたりする恐れ がある。そこで，接触による摩擦の小さい構造(3K(7) (9) あるいは, 逆に摩摖を利用して駆動する方法 ${ }^{(10)(11)}$ が 提案されている。前者の一方法として，著者らはこれ まで高温超電導体（以下，HTSC) と永久磁石（以下， PM）を用いた浮上型のリニアアクチュエータを報告 してきだ(9)(12) (14)。

更に，HTSCを利用した非接触型のアクチュエー タの利点としては以下のことが挙げられよう。従来の ボールベアリングを用いたアクチュエータ（ボールベ 
アリングの接触による粉塵と潤滑油が污染の原因とな る）に比べて非常にクリーンなものができる。そこ で, 真空装置やクリーンルームなどのクリーンな環境 での応用が期待されている(15)。しかし，HTSCを利 用することの制約として, 液体窒素による冷却が不可 欠である点がある。しかし，この制約も，例えば真空 装置〔真空引きをするときに液体窒素 $(77 \mathrm{~K})$ を利 用するつへの応用を考えれば，解消することが可能で ある。

そこで, 真空装置への応用を考えて, HTSCを用 いた真空内で駆動可能なりニアマイクロアクチュエー 夕を開発した ${ }^{(16)}$ 。更に改良を加えて，2方向に動くマ イクロアクチュエータを製作し，その動作を確認し た。

本論文では，真空内で 2 方向（平面）駆動を実現し たマイクロアクチュエータの構造, 動作原理, 実験装 置（真空用の HTSC 冷却装置など），そしてその駆動 特性について報告する。

\section{2. アクチュエータの構造と動作原理}

図1に2 方向に駆動するアクチュエータの構造を示 す。スライダには, 垂直方向に磁化したPM を用い た。ステータは，Y系の HTSCとその上にある 2 組 の絶緑膜（ポリイミド）上に形成された銅の電極から なる。図1に示すように，ステータの 2 組の電極就 互い直交するように重悋合せてある。そして，ポリイ ミドによってそれぞれの電極は絶縁されている。

さて, 液体窒素で HTSC 臨界温度以下に冷却す ると, PM と HTSC間に働く磁気反発力で PM は浮 上する。この磁気反発力は, 主としてピン止め力に起 因する(18)。ピン止め力は，HTSCの内部に侵入した 磁束の周りに巻付くように流れる超電導電流 (侵入磁 束と同方向の磁界を作る问きに流れる)によって, 侵 入した磁束の位置を束縛する力である。更に, ピン止 め力は浮上した $\mathrm{PM} に$ にピン止め力以下の外力を水平 方向から加えても, 力の加わる前の位置に PM を戻 す働きする。この力は, アクチュエータの位置制御 に有効なものになる。

次に, 駆動原理を説明する。HTSC上にPM を浮 かせた状態で，X力向に駆動するための電流を図 1 の ような向きに流すと, PMの磁界と駆動電流間に働く ローレンッカで PM は電流に引きつけられて移動す る。

この駆動原理を図 2 を使ってもう少し詳しく説明す る。まず, PMは厚さが薄く, そして厚み方向に均一 に磁化されていれば, 図2のようにPMを電流ルー

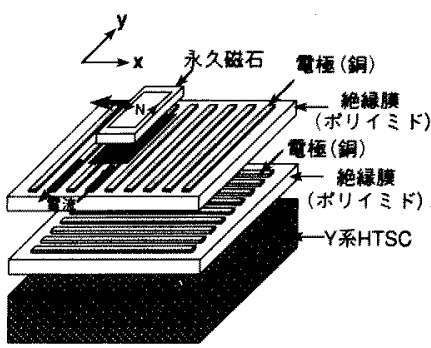

図 12 方向駆動アクチュエータの構造 Fig. 1. Structure of two-directional microactuator.

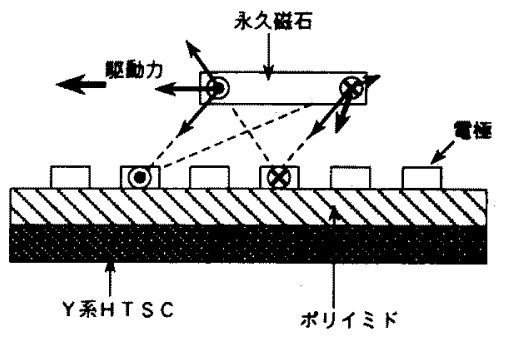

図 21 方向駆動の原理

Fig. 2. Principle of one directional actuation.

プに置換えてもよいだろう。図 2 の矢印の向きに磁石 を動かす場合，駆動力に関与するPM の電流は紙面 に垂直な成分である。2本の電極を選び，PM の電流 ループと同じ向きの往復電流を流すと, PMには吸引 力が働いて横方向に移動する。このとき，PMには下 方向の吸引力が働くが,この力よりも HTSC と PM 間の磁気反発力のほうが強ければ PMは浮上した状 態で横方向に移動することができる。そして, 電流を 通電する電極を進行方向に沿って切換えると, スライ ダは 1 方向に駆動する。

更に， $X$ 方向用駆動電流と $Y$ 方向用駆動電流を同 時に流して, $X Y$ の歌動を組合せると,ループ状や ステップ状に動かすことが可能となる。つまり，両方 向用の駆動電流は直交しているので, 一方の駆動力は 他方の駆動力と干渉することはない。

\section{3. 実験装置について}

〈3.1〉実験に用いたアクチュエータ まず，ス ライダを 1 方向に動かして基本駆動特性を調べ, 次に 2 方向に動かす。ここでは，1方向用と 2 方向用の 2 種類のスライダを用いた。図 3 に 1 方向駆動用スライ ダと電極を示す。図 4 に 2 方向駆動用スライダと電極 を示す。表1にスライダに使用したPMの寸法と磁 


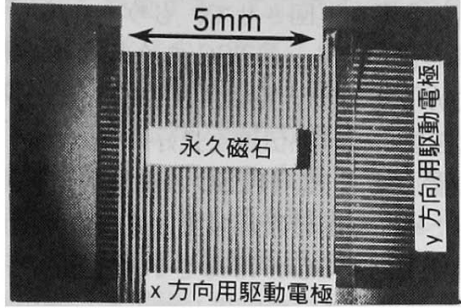

図 31 方向駆動内スライダと駆動電極 Fig. 3. A slider and driving electrodes of one directional actuator.

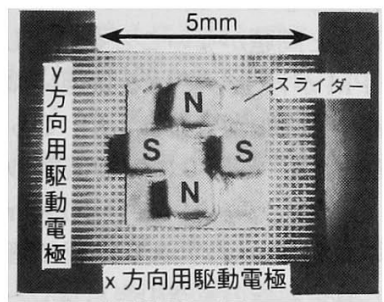

(a) スライダとステータ

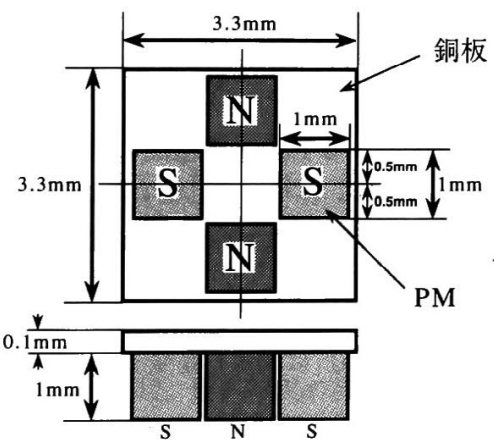

(b) スライタ

図 42 方向駆動用スライダと駆動電極 Fig. 4. A slider and driving electrodes of two directional actuator.

表 1 スライダに使用した PM の寸法と磁気特性 Table 1. Size and magnetic characteristics of PM for the slider.

\begin{tabular}{c|c|c|c|c}
\hline 用途 & $\begin{array}{c}\text { 寸法 } \\
\left(\mathrm{mm}^{3}\right)\end{array}$ & $\begin{array}{c}\text { 表面磁 } \\
\text { 東密度 } \\
B_{s}(\mathrm{G})\end{array}$ & $\begin{array}{c}\text { 残留磁束密度 } \\
B_{r}(\mathrm{kG})\end{array}$ & $\begin{array}{c}\text { 保磁力 } \\
H_{c b}(\mathrm{kOe})\end{array}$ \\
\hline 1 方向 & $1 \times 4 \times 0.3$ & 550 & - & - \\
\hline 2 方向 & $1 \times 1 \times 1$ & - & $6.1 \sim 6.7$ & $4.6 \sim 5.5$ \\
\hline
\end{tabular}

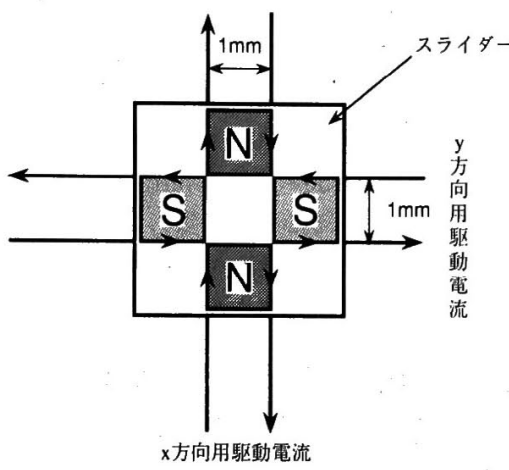

図 52 方向駆動の原理

Fig. 5. Principle of two directional actuation.

表 2 ステータ用の HTSC の寸法と超電導特性 Table 2. Size and superconducting characteristics of HTSC for stator.

\begin{tabular}{c|c|c|c|c}
\hline 試料 & 寸法 & $\begin{array}{c}\text { 臨界温度 } \\
T_{c}(\mathrm{~K})\end{array}$ & $\begin{array}{c}\text { 臨界電流密度 } \\
J_{c}\left(\mathrm{~A} / \mathrm{m}^{2}\right)\end{array}$ & $\begin{array}{c}\text { 下部臨界磁界 } \\
H_{c 1}(\mathrm{~A} / \mathrm{m})\end{array}$ \\
\hline $\mathrm{Y}$ 采 & $\begin{array}{c}\text { 直径 }: 25 \mathrm{~mm} \\
\text { 厚さ }: 2 \mathrm{~mm}\end{array}$ & 90 & $2.1 \times 10^{6}$ & $1.0 \times 10^{3}$ \\
\hline
\end{tabular}

注）試料は固相反応法で作成した。

気特性を示す。ここで，図 5 に示すような PM の配 置と駆動電流を組合せることで, $X$ と $Y$ の両方向に 同等の駆動力がスライダに働くようにできる。更に, この PM の配置ではスライダに働く下方向の吸引力 は，スライダの中心線上に作用する。したがって，駆 動時にスライダは傾くことなく垂直方向に安定した駆 動が可能である。

表 2 にステータに使用したY 系HTSC の寸法と超 電導特性を示す。ここで，Y系を選択したのは, 著 者らが以前に行った実験の結果(17) から，Y系の焼結 体は $\mathrm{Bi}$ 系焼結体に比べて, $\mathrm{PM}$ の水平方向の移動を 妨げる制動力 ${ }^{(19)}$ (ピン止め力に起因する)・の值が反 発力に比べて小さいことを考慮したためである。

図 3 と図 4 に示した $X$ 方向用と $Y$ 方向用のパター ン電極は垂直に交差するように，エポキシ系接着剤を 用いて接着されている。両方向の 25 本の電極に駆動 電流を流す。駆動電極の（線幅, ピッチ, 厚さ）は $(60 \mu \mathrm{m}, 180 \mu \mathrm{m}, 20 \mu \mathrm{m})$ である。こつパターン電極

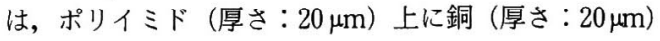
が圧延されたフィルムをフォトリソグラフィとウェッ トエッチング（市販のプリント基板用エッチング液を 使用）して製作した。

〈3・2〉真空用冷却装置 今回は, 真空内でアク 
チュエータを駆動させるので, HTSCを間接的に冷 却する必要がある。そこで, 図6のような冷却装置を 作製した。冷却装置は，ステンレス鋼のパイプ（外 径：約 $6.25 \mathrm{~mm}$ ）と厚さ $0.5 \mathrm{~mm}$ の銅板とはんだ付 けで作った冷却箱 $\left(30 \times 50 \times 5 \mathrm{~mm}^{3}\right)$ からなる。ステ ンレス鋼のパイプと冷却箱は, 銀のろう付けで液体窒 素が外部に漏れないように取付けてある。片方のステ ンレス鋼パイプで液体窒素を冷却箱に送り込み，冷却

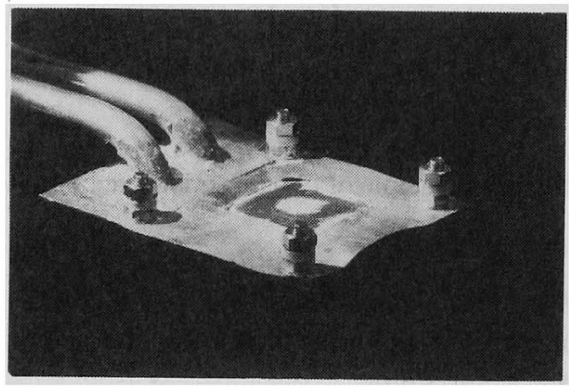

図 6 真空用冷却装置

Fig. 6. Cooling unit under vacuum condition.

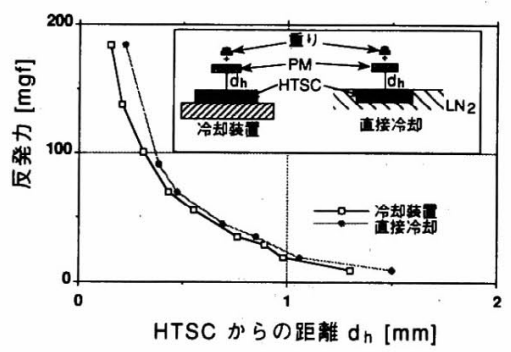

図 7 本冷却装置の場合と直接冷却の場合の PM の反発力の比較

Fig. 7. Comparison of repulsive force between using cooling unit and direct cooling.

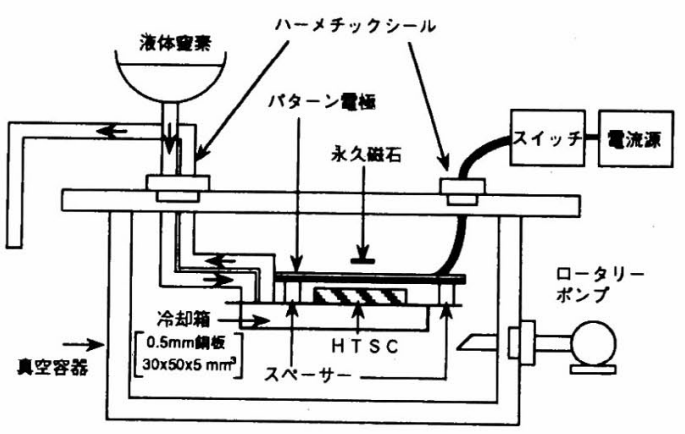

図 8 実験装置の全体図

Fig. 8. Experimental setup.
箱中で液体窒素を巡回させて，もう一方のパイプから 液体窒素を排出する。HTSC の冷却は冷却箱の上面 の銅板を介して行う。更に，HTSC と銅板間に放熱 グリースを塗って，熱伝達を良好に保った。

実験装置の構造上，HTSC の温度を直接測定でき なかったため, 今回の冷却装置と直接液体窒素で冷却 した場合との HTSCの冷却され具合を, HTSC と PM 間の反発力の測定で評価してみた。測定した反発 力は磁界中冷却による測定値である。PM の浮上高さ の測定には，レーザ変位計（KEYENCE LC-2320） を使用した。HTSCを直接液体窒素で冷却した場合 と今回の冷却装置で冷却した場合の PM の反発力の 比較を図 7 に示す。この結果から, HTSCの冷却に 関してはほとんど問題がないことを確認した。また， $\mathrm{HTSC}$ 上を $\mathrm{PM}$ が浮上している状態において, この 冷却装置の液体窒素の消費量は $4 l / \mathrm{h}$ であった。

〈3・3〉実験装置図 8 に実験装置の全体図を示 す。ガラスのデシケータ（直径： $150 \mathrm{~mm}$, 深さ： $90 \mathrm{~mm}$ ) に厚さ $10 \mathrm{~mm}$ のアクリル板で蓋をして真空 容器とした。真空容器の真空引きにはロータリーポン プを用いた。図 8 に示すように真空容器の蓋と液体窒 素を流すステンレス鋼パイプと配線の接合部分はゴム とエポキシ系接着剤によるハーメチックシールがされ ている。真空装置の真空度をピラニー真空計で測定し たところ，真空度は 1.1 Torr であった。

駆動力に影響する PM と電極間の間隔は，スペー サの高さを変えることで調整可能である。また，通電 電極の切換えは手動のロータリースイッチで行った。 更に, それに付随したスイッチで駆動電流のパターン 〔電流を 1 本の電極に流す, 2 本にループ状（間隔 0.5 $\mathrm{mm}$ または $1 \mathrm{~mm})$ に流す了を変えることができる。

\section{4. 実験結果および検討}

図 9 に真空中で HTSC を冷却したときのスライダ の浮上の様子を示す。このスライダは HTSCより $1.3 \mathrm{~mm}$ 浮上した。この状態で, 駆動電極に電流を流

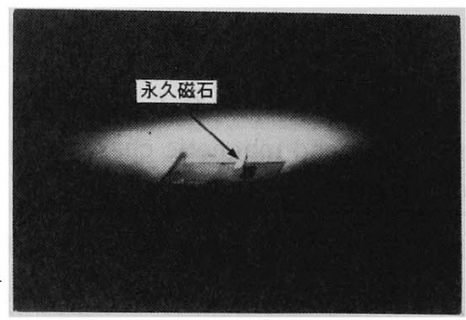

図 91 方向スライダの浮上の様子

Fig. 9. Levitation of one directional slider. 
してスライダを駆動する。ここでは，まず1方向に駆 動した場合の特性について述べ, 次に $X, Y の 2$ 方 向に駆動した場合の特性を述べるものとする。

\section{〈4・1〉 1 方向駆功時の敦作特性}

（1）駆動電流パターンの影響文ず, 駆動電流 の流し方を変えてスライダの動特性を比較した。図 10 に示すように電流を駆動電極 1 本だけに流す場合, 磁石の幅の半分の間隔 $(0.5 \mathrm{~mm})$ にループ状に流す 場合，そして磁石の幅と同じ間隔 $(1 \mathrm{~mm})$ にループ 状に流す場合についてスライダの駆動特性を比較し た。その結果, 駆動電流の值が小さく, スライダが垂 直方向に安定して動くのは, 磁石の幅と同じ間隔 (1 mm）にループ状に電流を流した場合であった。そし て，スイッチの切換えに追従してスライダが動くため の最小駆動電流は $150 \mathrm{~mA} ゙$ てた。また， $X ， Y$ 両方向に同じように動くことを確認した。以下，磁石 の幅と同じ間隔でループ状に電流を流した場合の 1 方 向駆動特性を示す。

（2）スライダの浮上特性駆動電流に対するス ライダの高さ方向の変動を調べた。測定にはレーザ変 位計を用いた。図 11 に駆動電流に対する駆動電極か

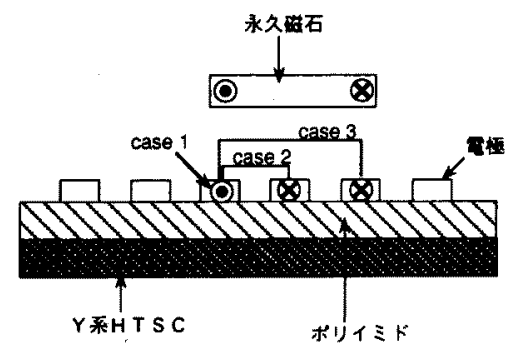

図 10 駆動電流の流し方

Fig. 10. Pattern of driving current.

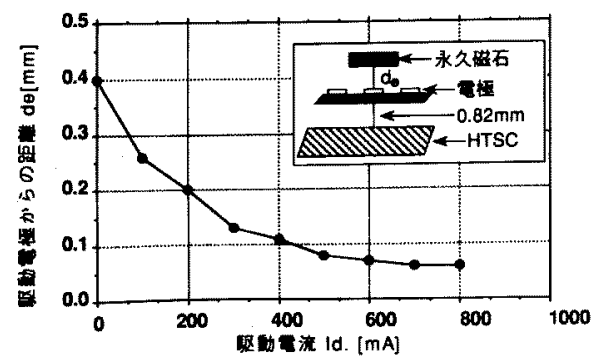

図 11 駆動電流に対する 1 方向用スライダ の浮上高さ

Fig. 11. Driving current vs. levitation height of one directional slider.

電学論A, 112 巻 12 号, 平成 4 年
らのスライダの浮上高さを示す。駆動電流を大きくし ていくと, 下方向に引きつける力が強くなってスライ ダの浮上高さが減少する。最小駆動電流 (150 mA)

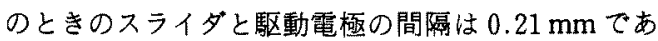
る。

（3）スライダの動特性次に, 駆動電極に順次 方形波状の電流が流れるよう電流を切換えてスライダ の変位の動特性を测定した。測定には，高速ビデオ (Kodak Ektapro EM, 最高 12,000こま/秒) を用い た。図 12 に駆動電流 $400 \mathrm{~mA}$ のきの動特性を示す。 (a)図のグラフは時間に対するスライダの変位を示し たものである。スライダが $3 \mathrm{~mm}$ 移動するのに要した 時間は，0.3sである。また，スライダの進行方向

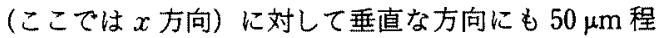
度の変位が観測された。そして，(b)図のグラフは時 間に対するスライダの速度特性を示したものである。 この速度は，(a)図の結果における测定点と測定点間 の変位をその䦓の経過時間で割った值とした。これよ り，スライダの瞬間最大速度は $37 \mathrm{~mm} / \mathrm{s}$ と求められ た。

(4) ステップ応答 更に, スライダのステップ 応答を測定した。図 13 に駆動電流 $400 \mathrm{~mA} の と き の$ スライダのステップ応答 (1ピッチ: $180 \mu \mathrm{m})$ を示 す。これょり，4 ms 程度でステップ応答は終了して いるのがわかる。ただし，画像を用いた測定の都合

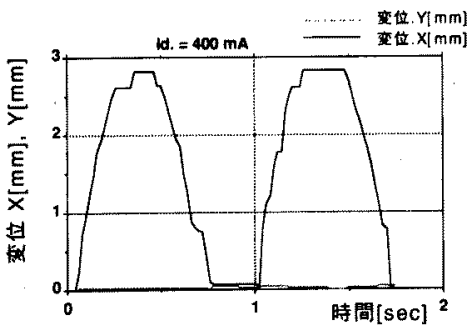

（a）変位特性

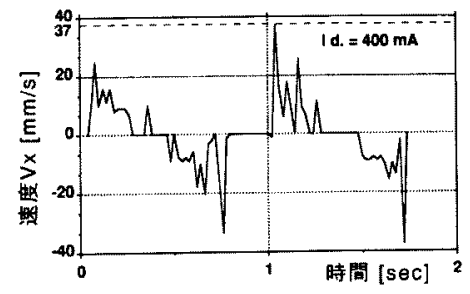

(b) 速度特性

図 121 方向駆動アクチュエータの動作特性 (駆動電流： $400 \mathrm{~mA}$ )

Fig. 12. Operation of one directional actuator (current: $400 \mathrm{~mA}$ ). 


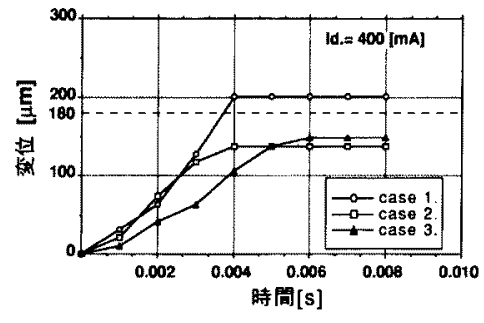

図 131 方向駆動アクチュエータのステップ応答 (駆動電流：400 mA)

Fig. 13. Step response of one directional actuator (current : $400 \mathrm{~mA}$ ).

上，電流波形の立上りに対してスライダが始動する時 点の遅れは測れなかった。今後, 検討する必要があ る。ここでは，スライダが電極ピッチ以下の変位甬電 極ピッチ以上の変位で止まる，すなわち負と正の定常 偏差 (応答值と目標値の差) が生じる。

〈4・2〉 X, Y 2 方向駆動時の動作特性 先の結 果から，駆動電流が最小でかつ，スライダが垂直方向 に安定動作を行うのは，磁石の幅と同じ間隔 $(1 \mathrm{~mm})$ にループ状に電流を流した場合であることを確認し た。そこで，両駆動電極に磁石の幅と同じ間隔（1 $\mathrm{mm} ＼mathrm{~ に ル ー フ ゚ 状 に 電 流 を 流 し ， 2 ~ 方 向 用 ス ラ イ タ ゙ を ~}$ 動かした。実験の結果, 両方向に駆動電流を流して, スライダが任意の大きさのループ状や階段状に動くこ とを確認した。このときの最小駆動電流は，X方向 駆動電流：650 mA， $Y$ 方向駆動電流：500 mA であ る。

（1） スライダの浮上特性 2 方向駆動用スライ ダの HTSC からの浮上高さは $0.86 \mathrm{~mm}$ であった。図 14 に駆動電流に対するスライ歹駆動電極からの浮 上高さを示す。この結果から, 駆動電流の増加に対し て駆動電極からのスライダの浮上高さは, 直線的に減 少していることがわかる。

（2）スライダの動特性図15に両方向の駆動 電極に電流を流したときの，1 方向駆動特性を示す。 (a)図のグラフは時間に対するスライダの変位を示し たものである。スライダが $2.5 \mathrm{~mm}$ 移動するのに要し

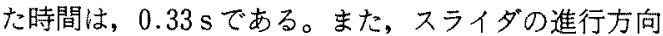
(ここでは $Y$ 方向）に対して垂直な方向にも，3\%ほ どの変位が観測された。そして，(b)図の速度特性か らスライダの瞬間最大速度は $33 \mathrm{~mm} / \mathrm{s}$ と求めら れた。

\section{〈4・3〉 実験結果の検討}

（1）1方向に駆動した場合 1 方向動作で駆動

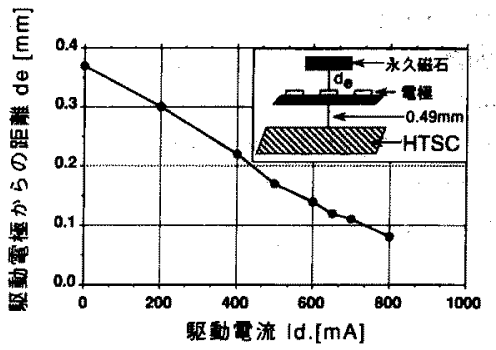

図 14 駆動電流に対する 2 方向駆動用 スライダの浮上高さ

Fig. 14. Driving current vs. levitation height of two derectional slider.

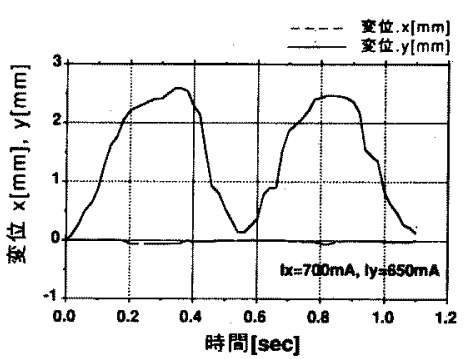

(a) 変位特性

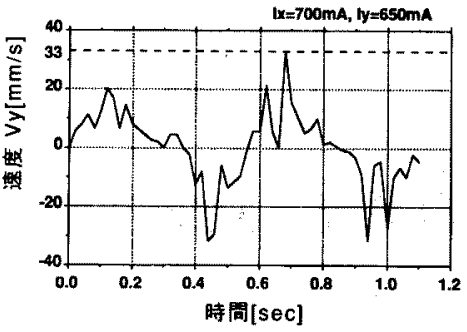

(b) 燠度特性

$X$ 駆勳電流: $700 \mathrm{~mA}, Y$ 駆動電流：650 mA

図 152 方向駆動アクチュエータの動作特性 Fig. 15. Operation of two directional actuator.

電流の配置パターンを変えて実験を行った。磁石の幅 と同じ間隔（1 mm）に駆動電流をループ状に流した 場合に, 駆動電流が最小でスライダが垂直方向に安定 して駆動した。以前に報告した 1 方向型アクチュエー $夕^{(16)}$ に比べて, 最小駆動電流值が非常に小さくなっ ている $(600 \mathrm{~mA} \rightarrow 150 \mathrm{~mA})$ 。これは，電流を電極 1 本に流した場合よりもループ状に流したほうが，スラ イダに働く力での水平方向成分(つまり駆動力)の割合 が大きくなるためだと思われる。また，垂直方向に安 
定して駆動する理由としては，PM の両端には同等の 力が重直方向に㗢いて，PM が傾かずに駆動できると 考えられる。

図 12(a)のスライダの動特性で, 進行方向に対し て垂直な方向にも変位が観測された。これは，ピン止 め力に起因していると思われる。これについて詳しく 説明する。磁束は HTSC 内部のピン止めセンタのと ころに侵入し，磁束はピン止め力によって侵入した場 所に束縛される。ここで，PMを動かしたときに磁束 にピン止め力以上の力がかかると, 磁束はピン止めセ ンタから脱出して次のピン止めセンタに移動する。こ のときのPMの静止安定点が移動する前の静止安定 点より進行方向に対して垂直方向にずれると, PMに も進行方向と垂直な方向にピン止め力でずれが生じる と思われる。

図13のステップ応答の測定結果において，目標値 $(180 \mu \mathrm{m})$ に収束しない現象がみられる。これは，駆 動力に対してピン止め力が摩擦のように㗢いて目標值 に合致する前に停止してしまうのではないかと推測さ れる。

（2） $X, Y 2$ 方向に駆動した場合 $X, Y 2$ 方 向駆動可能なスライダを製作し， 2 方向に動作するこ とを確認した。ここで, 最小駆動電流の値が $X$ 方向 と $Y$ 方向では異なっている。これは，実際のスライ ダの PM の配置が理想的な図 4(b)のようではなく, スライダの中心線から多少ずれている。このため, 駆 動力に関与する磁界の強さが $X$ と $Y$ 方向では異な り，両方向の最小駆動電流に差が生じると考えられ る。

また， 1 方向の特性に比べて，最小駆動電流值が大 きくなっている。これには，二つの原因が考えられ る。一つは 2 方向駆動用に用いたPM が, 磁性体の 粒子を有機バインダで固めたボンド磁石であるので, スライダに用いた PM 全体の磁気エネルギーが, 磁 性体のバルクから切出した 1 方向用スライダのPM よりも小さく(20), 結果として㵊小駆動電流が大きく なると考えられる。もう一つの原因に，ピン止め力の 影響が考えられる。今回の PM の磁石の配置からス ライダの下側で磁束線の分布は閉じた形になり, HTSCに侵入する磁柬線の割合が 1 方向用スライダ のPM の場合よりも膏くなる。これにより,スライ ダに㗢くピン止め力か゚大きくなり，その影響も受けて 最小駆動電流の值が大きくなるものと思われる

\section{5.おわりに}

$Y$ 系超電導体を用いた異空内で $X, Y$ 駆動するマ
イクロアクチュエータを開発し，スライダが 2 方向に 駆動することを確諗した。スライダを1方向に動かす

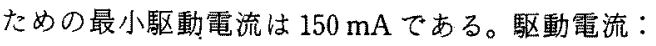
$400 \mathrm{~mA}$ 時の瞬間最大速度は, $37 \mathrm{~mm} / \mathrm{s}$ である。ま た、スライダを $X, Y 2$ 万向に動かすための最小駆 動電流は， $X$ 方向用駆動電流：650 $\mathrm{mA} ， Y$ 方向駆甥 電流：500 mA である。

今回は, 真空内でのアクチュエータの動作を確認し たに過ぎない。従って, 冷却效率の改善, スライダの 位置を検出して駆動電流の切换えをコンピュータ制御 をするなどの様々な課題が残されている。

本研究を行う際に, 多くの方々の御支援, 御協力を いただいた。特に，ソウル大学金容權助教授には, アクチュエータの設計段階で御助言をいただいた。日 本アイ・ビー・エム東京基礎研究所古烟智武氏と東京 大学修士課程小林 大氏には,アクチュエータと実 験装置の製作において，御協力と御助並をいただい た。また，株式会社キーエンスには，スライダの浮上 特性を測定するためのレーザ変位計を貸していただい た。これらの方々に樑く感謝いたします。

(平成 4 年 3 月 27 日受付)

\section{文 献}

(1) K, J. Gabriel, W. S. N. Trimmer \& M. Mehregany: Technical Digest of The 4th International Conference on SolidState Sensors and Actuators (Transducers'87), Tokyo, p. 853 (1987)

(2) M. Mehregany, S. F. Bart, L. S. Tavrow, J. H. Lang, S. D. Senturia \& M. F. Schlecht: Sensors \& Actuators, A21-23, p. 173 (1990)

(3) W. C. Tang, T. H. Nguyen \& R. T. Howe: Technical Digest, IEEE Micrro Electro Mechanical Systems Workshop, Salt Lake City, p. 53 (1989)

(4) 藤田博之：篦学諭 D, 108, 205 (昭 63)

(5) K. J. Gabriel, F. Behi, R. Mahadevan \& M. Mehregany: Sensors \& Actuctors, A21-A23, 184 (1990)

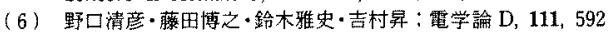
(구 $3-7$ )

(7) T. Hirano, T. Furuhata, K. J. Gabriel \& H. Fujita: J. Mi. croelectromechanical Systems, 1, No. 1, 52 (1992)

(8) K. S. J. Pister, R. S. Fearing \& R. T. Howe: Technical Digest of IEEE Micro Electro Mechanical Systems Workshop, Napa Valley, California p. 67 (1990)

（9）金容藏・桂井被・藤田博之：低温工学，26、No.1，37（平 3)

(10) M. Sakata, Y. Hatazawa, A. Omodaka, T. Kudo \& H. Fujita: Sensors \& Actuators, A21-A23, 168 (1990)

(11) T. Furuhata, T. Hirano \& H. Fujita: Technical Digest of 1991 International Conference on Solid-State Sensors and Actuators (Transducers'91), San Francisco, p. 1056 (1991)

(12) Y. K. Kim, M. Katurai \& H. Fujita: Sensors \& Acutuators, 20, 33 (1989)

(13) Y.-K. Kim, M. Katurai \& H.Fujita: Proceedings of Micro Mechanical Systems, Napa Valley, California, p. 61 (1990)

(14) Y.K. Kim, M.Katurai \& H. Fujita: Sensors \& Acutuators A, 29, 143 (1991) 
（15）荻原宏康 - 森下明平 - 笠原紀子 - 明石征邦：平 3 秋季低温 超電導学会講演集, p. 45

（16）前田吉彦・合原一幸・藤田博之：平 3 秋季低温・超電導学会 講演集, p. 49

（17）前田吉彦·合原一幸·藤田博之：電学論 D, 111, 590 (平 3-7)

（18）電気学会大学講座 超電導工学 (改訂版)，(昭 63）オーム社

(19) F. C. Moon, K.C. Weng \& P.Z. Chang: J. Appl. Phys., 66, No. 11,5643 (1989)

（20）猪俣浩一郎：新素材 100 希土類磁石（平 2）冬樹社

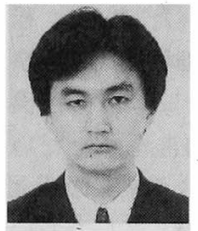

\section{前田吉 彦(准員)}

昭和 40 年 12 月 11 日生。平成 2 年 3 月東京電機大学工学部電気工学科卒業。 現在, 同大学大学院工学研究科電子工学 専攻修士課程在学中。セラミック系超電 導体の応用に関する研究に従事。低温工学協会会員。

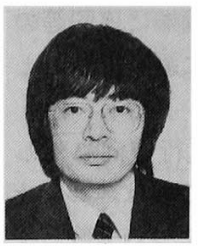

合 原 一 幸 (正員)

昭和 29 年 6 月 23 日生。 57 年 3 月東 京大学大学院電子工学博士課程修了。現 在, 東京電機大学工学部電子工学科助教

授。工学博士。主として, カオスニュー ラルネットワークおよびニューラルコンピューティング産 業応用研究に従事。電子情報通信学会, 生物物理学会, 電 気設備学会, 日本 ME 学会, INNS, SMB 学会会員。

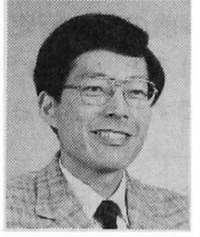

藤 田博之（正員）

昭和 27 年 12 月 13 日生。 55 年 3 月東 京大学大学院博士課程修了。工学博士。 同年, 4 月上り東京大学生産技術研究所 講師, 56 年 5 月同助教授となり, 現在 に至る。主として, マイクロメカトロニクス, マイクロア クチュエータ, 極低温・超電導技術の研究に従事。IEEE, SICE，低温工学協会会員。 